\title{
Effects of pre-slaughter fasting on broiler welfare, meat quality, and intestinal integrity
}

\section{-Author(s)}

Pereira REP

Martins MRFB 2

Mendes $A^{1}$

Almeida PAZ $\mathrm{ICL}^{3}$

Komiyama $\mathrm{CM}^{1}$

Milbradt EL

Fernandes BC da S

Departamento de Produção Animal Universidade Estadual Paulista, campus de Botucatu.

2 Departamento de Anatomia, Instituto de Biociências Universidade Estadual Paulista campus de Botucatu.

3 Faculdade de Ciências Agrárias, Universidade Federal da Grande Dourados.

\section{-Mail Adress}

*Corresponding author e-mail address

E-mail: marcia@ibb.unesp.br

\section{-Keywords}

Broiler industry, stress, intestinal morphology, intestinal morphometrics.

\section{ABSTRACT}

The Brazilian Ministry of Agriculture (MAPA) regulations establish 12 hours as the maximum pre-slaughter fasting period for broilers; however, many processing plants have considered this time is not sufficient, and consequently return the birds to the farms, with consequent economic losses and welfare problems. Therefore, it is necessary to investigate the possible effects of longer pre-slaughter fasting times. The objective of the present study was to evaluate the effect of pre-slaughter fasting times longer than those established by MAPA on broiler welfare, breast meat quality, and intestinal integrity. Forty 42-d-old broilers were submitted to different pre-slaughter fasting times: group I: 6 hours, group II 9h, group III 12h, and group IV 15h. Bird welfare was assessed before slaughter. After sacrifice, intestinal samples were collected to assess their morphology and morphometrics, and the Pectoralis major muscle was analyzed for $\mathrm{pH}$ and color. There was no influence ( $p>0.05)$ of treatments on breast muscle $\mathrm{pH}$ or color.There were no significant changes in intestinal morphometrics $(p<0.05)$. Bird behavior was affected $(p<0.05)$, suggesting that welfare was impaired as fasting time increased, but no differences in the analyzed parameters were detected between broilers fasted for 12 or 15 hours. It was concluded that the behavioral differences between birds fasted for 12 and 15 hours are not sufficient to assert that those fasted for 15 hours were in worse welfare conditions.

\section{INTRODUCTION}

Pre-slaughter feed fasting, which consists of feed withdrawal a few hours before slaughter, is an important step in broiler processing as it affects meat yield and quality. Its objective is to reduce carcass contamination during processing, and therefore, the need of reprocessing (Duke et al., 1997; Northcutt et al., 1997).

The increasing trade of deboned parts and processed chicken products brought to light other concerns, such as the effect of fasting on meat quality traits, particularly $\mathrm{pH}$, tenderness, cooking loss, and meat chemical composition (Ali et al., 1999; Beraquet, 1999; Berri, 2000). On the other hand, the scientific and technical communities are also increasingly concerned with animal welfare. This concept has changed in the last few decades because more people are now living in cities than in the country and their purchase power has grown, and therefore public demands on environmental protection and on the provision of proper welfare of livestock (Edwards, 2004; Nääs, 2005; Moura et al., 2006). This has led to further studies on preslaughter stress and to changes in the production systems by food companies, aiming at preventing any negative public perception of their products. 
The intestinal epithelium is especially influenced by the absence of food. For instance, villus height is significantly reduced after $24 \mathrm{~h}$ fasting (Yamauchi et al., 1996; Maiorka et al., 2002). In the study of Shamoto \& Yamauchi (2000), broiler villus height was reduced after $72 \mathrm{~h}$ fasting, and significantly increased three hours after refeeding.

Considering that the regulation of the Brazilian Ministry of Agriculture (MAPA) demands no more than $12 \mathrm{~h}$ fasting, the knowledge on the effects of longer fasting periods on broiler welfare, meat quality, and intestinal wall integrity should be very useful.

\section{MATERIALS AND METHODS}

In the experimental poultry house of the School of Veterinary Medicine and Animal Science (FMVZ) of UNESP, Botucatu, Brazil, 200 male Cobb broilers were housed at an average density of $30 \mathrm{~kg} / \mathrm{m}^{2}$. Water was supplied ad libitum until catching, and feed was offered until the beginning of the fasting period.

At 42 days of age, 40 birds were taken in specific transport crates to FMVZ experimental processing plant, and were distributed in four groups of 10 birds submitted to four different pre-slaughter fasting times:group I: 6 hours, group II: 9 hours, group III: 12 hours, and group IV: 15 hours. During lairage, broiler behavior was monitored every three hours. At the end of the fasting times, birds were electrically stunned and bled by cutting the jugular vein and carotid artery. Carcasses were scalded, eviscerated, and chilled.

Welfare was assessed in the lairage area of the experimental processing plant.Birds were remained in the transport crates at a density of 10 per cage during the welfare assessment. Crates were protected from direct sunlight, and environmental temperature ranged between 17 and $26^{\circ} \mathrm{C}$. Welfare was assessed by observation of bird behavior, and the activities performed during 10 minutes were recorded for each fasting time $(6,9,12$, and 15 hours). Observations were plotted in frequency histogram, which showed the respective proportion of time used for the following behaviors: thermoregulation (panting), active or inactive (standing or sitting), distressed, excessive chirping. It must be noted that sitting, standing, and distressed can only be performed by the bird one at the time. Distressed in this study was considered when the birds does not keep standing or sitting, demonstrating discomfort with the situation, according to the methodology adapted from Campos (2000).
Breast meat $\mathrm{pH}$ was determined directly using a $\mathrm{pH}$ meter (Sentron, model 1001) coupled to a probe (Sentron, type LanceFET, model 1074001) with thin penetrating tip inserted $0.5-1.0 \mathrm{~cm}$ below the surface of the left side of the breast muscle (Pectoralis major). This measurement was performed in all carcasses of all treatments two hours post-mortem.

Breast meat color was measures using a spectrophotometer (Konica Minolta CR 400, CIELab system) to determine $L^{*}$ (luminosity), $a^{*}$ (redness), and $b^{*}$ (yellowness) values inThree different points of the ventral surface and in the middle of the cranial section of the Pectoralis major. Breast meat was exposed to the air for 30 min before color measurements, as proposed by Van Laack et al. (2000).

Segments measuring approximately $2 \mathrm{~cm}$ were collected from the duodenum, jejunum, and cecum and immersed in Bouin solution for $24 \mathrm{~h}$, according to the specifications of McManus \& Mowry (1960). After being fixed and sectioned, the material was dehydrated by immersion in graded series of alcohol, cleared by three passages in xylol, and embedded in Polyfinparaplast. Tissues were cut with the aid of an automatic microtome (Leica, RM-2145) to obtain $4-\mu \mathrm{m}$ thick cuts in a semi-serial sequence of a $30 \mu \mathrm{m}$ cut. Tissue sections were stained with periodic acid Schiff (PAS) and Masson trichrome stains, according to the methodology of McManus \& Mowry (1960) and Behmer et al. (2003). Mucosa, submucosa, muscularis mucosa (circular internal and longitudinal external layers) and serosa thickness of the collected intestinal segments were determined by image analysis with the aid of an image-capture software program (Leica Qwin Lite 3.0). Five measurements were performed per layer.

Welfare data were submitted to analysis of variance for non-parametric data using the SAEG (1998) statistical package, and means were compared to the Mann Whitney test at 5\% significance level.

The other results were submitted to analysis of variance using SAS (2004) statistical package. Means were compared by the test of Tukey, using the General Linear Models (GLM) procedure) at 5\% significance level.

\section{RESULTS AND DISCUSSION}

Fasting time influenced $(p<0.05)$ the evaluated behaviors, suggesting worse welfare as fasting time increased (Table 1). Other studies reported that broiler stress is directly proportional to fasting time 
Table 1 - Broiler behavior in lairage.

\begin{tabular}{|c|c|c|c|c|c|c|c|c|c|c|c|c|c|}
\hline \multirow[b]{2}{*}{ Time } & \multirow[b]{2}{*}{ N. birds } & \multicolumn{2}{|c|}{ Standing } & \multicolumn{2}{|c|}{ Sitting } & \multicolumn{2}{|c|}{ Panting } & \multicolumn{2}{|c|}{ Feather-pecking } & \multicolumn{2}{|c|}{ Chirping } & \multicolumn{2}{|c|}{ Distressed } \\
\hline & & $n$ & $\%$ & $n$ & $\%$ & $n$ & $\%$ & $n$ & $\%$ & $n$ & $\%$ & $n$ & $\%$ \\
\hline $6 \mathrm{~h}$ & 40 & 8 & $20 \mathrm{a}$ & 32 & $80 \mathrm{~b}$ & 0 & $0 \mathrm{c}$ & 0 & $0 \mathrm{c}$ & 2 & $5 b$ & 0 & $0 \mathrm{C}$ \\
\hline $9 h$ & 30 & 4 & $13 b$ & 22 & $73 \mathrm{ab}$ & 0 & $0 \mathrm{c}$ & 0 & $0 \mathrm{C}$ & 3 & $10 \mathrm{~b}$ & 4 & $13 \mathrm{~b}$ \\
\hline $12 \mathrm{~h}$ & 20 & 2 & $10 \mathrm{~b}$ & 12 & $60 \mathrm{a}$ & 3 & $15 a$ & 1 & $5 b$ & 4 & $20 \mathrm{~b}$ & 6 & $30 \mathrm{a}$ \\
\hline $15 \mathrm{~h}$ & 10 & 0 & $0 \mathrm{c}$ & 5 & $50 \mathrm{a}$ & 1 & $10 \mathrm{~b}$ & 3 & $30 a$ & 7 & $70 \mathrm{a}$ & 5 & $50 \mathrm{a}$ \\
\hline
\end{tabular}

Means followed by different letters in the same row are statistically different by the test of Mann Whitney $(p<0.05)$.

(Mendes, 2001; Northcutt et al., 2003; Castro et al., 2008). In the present study, with 15 h of fasting, no birds were standing, there was a higher incidence of feather pecking, and chirping was more intense, suggesting that birds were distressed. However, the percentage of birds sitting and distressed was not different between 12 and $15 \mathrm{~h}$ of fasting. Behavioral adjustments occur faster than physiological adjustments, and therefore behavioral changes are reliable indicators of animal welfare. Agonistic behaviors, such as feather-pecking, as defined by Cast (1997), Martrenchar et al. (2000), and Marx et al. (2001), are associated to stress situations. Birds increasingly displayed agonistic behavior as fasting time increased, corroborating the hypothesis that welfare worsens as fasting time increases. However, this parameter was not different $(p>0.05)$ between broilers fasted for 12 or $15 \mathrm{~h}$.

There was no effect of treatment on breast meat $\mathrm{pH}$ (6h: $6.19 \pm 0.04 ; 9 \mathrm{~h}: 6.27 \pm 0.04 ; 12 \mathrm{~h}: 6.21$ \pm 0.04 ; 15h: $6.28 \pm 0.04 ; p>0.1), a *$ (6h: $2.98 \pm$ $0.39 ; 9 h: 2.73 \pm 0.39 ; 12 h: 2.82 \pm 0.39 ; 15 h: 3.26 \pm$ $0.39 ; p>0.1)$ e b* (6h: $1.04 \pm 0.41 ; 9 h: 2.47 \pm 0.41$; $12 \mathrm{~h}: 1.34 \pm 0.41 ; 15 \mathrm{~h}: 1.38 \pm 0.41 ; \mathrm{p}>0.1)$ values. However, $L^{*}$ value was higher with $9 \mathrm{~h}$ of fasting compared with the other fasting times (6h: 44.77 \pm 1.00a; 9h: $49.07 \pm 1.00 \mathrm{~b} ; 12 \mathrm{~h}: 45.00 \pm 1.00 \mathrm{a}$; 15h: $45.24 \pm 1.00 a b ; p<0.05)$. Nevertheless, all determined $L$ * values are within the range considered normal in literature, according to the chicken meat classification of Allen et al. (1998) in pale $\left(L^{*}>50.0\right)$ or dark $\left(L^{*}<45.0\right)$ or of Qiao et al. (2001), in pale $\left(L^{*}>53\right)$, dark $\left(L^{*}<46\right)$, or normal $\left(46>L^{*}<53\right)$. Differently from the present results, Castro et al. (2008), evaluating the effect of different fasting times $(3,6,9,12,15$, or $18 \mathrm{~h})$ on the breast meat of broilers reared in conventional systems, observed that $L^{*}$ values decreased as fasting time increased, despite the lack of statistical difference $(p>0.05)$.
Table 2 - Breast meat $\mathrm{pH}$ and color $\left(\mathrm{L}^{*}, \mathrm{a}^{*}, \mathrm{~b}^{*}\right)$ values of broilers submitted to different ante-mortem fasting times.

\begin{tabular}{lcccc}
\hline & \multicolumn{4}{c}{ Treatments (fasting times) } \\
\cline { 2 - 5 } & $\mathbf{6 h}$ & $\mathbf{9 h}$ & $\mathbf{1 2 h}$ & $\mathbf{1 5 h}$ \\
\hline $\mathbf{p H}$ & $6.19 \pm 0.04$ & $6.27 \pm 0.04$ & $6.21 \pm 0.04$ & $6.28 \pm 0.04$ \\
\hline L* & $44.77 \pm$ & $49.07 \pm$ & $44.92 \pm$ & $45.24 \pm 1.00$ \\
& $1.00 \mathrm{a}$ & $1.00 \mathrm{~b}$ & $1.00 \mathrm{a}$ & $\mathrm{ab}$ \\
$\mathbf{a}^{*}$ & $2.98 \pm 0.39$ & $2.73 \pm 0.39$ & $2.82 \pm 0.39$ & $3.26 \pm 0.39$ \\
$\mathbf{b}^{*}$ & $1.04 \pm 0.41$ & $2.47 \pm 0.41$ & $1.34 \pm 0.41$ & $1.38 \pm 0.41$ \\
\hline
\end{tabular}

Means followed by the same letter are not different by the test of Tukey $(P<0.05)$.

There was no effect ( $p>0.05)$ of treatments (6h, $9 \mathrm{~h}, 12 \mathrm{~h}, 15 \mathrm{~h}$ ante-mortem fasting) on duodenum (6h: 944.6; 9h: 932.5; 12h: 1010.0 and 15h: 957.9), jejunum (6h: 946.7; 9h: 944.2; 12h: 991.9 and 15h: 992.1) or cecum (6h: 419.9; 9h: 447.1; 12h: 443.1; 15h: 445.7) villi height (Fig 1, 2, and 3; Table 3). It must be noted that mucosa thickness affects villus height. Mucosa thickness in the evaluated intestinal segments is presented in Table 4 . These results are consistent with the findings of Thompson \& Applegate (2006), who observed that there are villi height, crypt depth, and cell migration and proliferation changes in the intestinal segments of birds submitted to long fasting times $(<24 \mathrm{~h})$, but these changes are not evident when short fasting times $(<24 \mathrm{~h})$ are applied. Duodenum and jejunum villi heights measured in the present study was consistent with those reported by Mitchel and Carlisle (1992) and Okamoto et al. (2009) of $938 \mu \mathrm{m}$, in average, in the jejunum and by Smith et al. (1990), of $1310 \mu \mathrm{m}$ and $850 \mu \mathrm{m}$ in the duodenum of broilers selected for fast growth and non-selected broilers, respectively.

The absence of villi height differences among broilers submitted to different pre-slaughter fasting times in the present experiment indicates that there was a balance between two cytological events (cell renewal and cell loss due to sloughing), suggesting that digestion, absorption, and intestinal integrity were not influenced by any of the fasting times, including $15 \mathrm{~h}$ of fasting (Figures 1, 2, and 3) 
Table 3 - Mucosa thickness ( $\mu \mathrm{m})$ of the duodenum, jejunum, and cecum of broilers submitted to different ante-mortem fasting times.

\begin{tabular}{lcccc}
\hline & \multicolumn{4}{c}{ Treatment } \\
\cline { 2 - 5 } Mucosa & $\mathbf{6 h}$ & $\mathbf{9 h}$ & $\mathbf{1 2 h}$ & $\mathbf{1 5 h}$ \\
\hline Duodenum & 944.6 & 932.5 & 1010.0 & 957.9 \\
Jejunum & 946.7 & 944.2 & 991.9 & 992.1 \\
Cecum & 419.9 & 447.1 & 443.1 & 445.7 \\
\hline
\end{tabular}

Means followed by different letters in the same row are statistically different by the test of Tukey $(p<0.05)$

\section{CONCLUSIONS}

It is concluded that 15 hours of pre-slaughter fasting does not impair breast meat quality and does not affect the morphology and the morphometrics of the duodenum, jejunum, and cecum of broilers, particularly when compared to 12 hours of fasting. The worse welfare of broilers detected after 12 hours of fasting demonstrates that increasing pre-slaughter fasting times increases bird distress.

\section{REFERENCES}

Ali ASA, Harrison A, Jensen JF. Effect of some ante-mortenestressors on perimorten and post-morten biochemical changes and tenderness in broiler breast muscle: a review. World's Poultry Science Journal 1999;55(4):403-414.

Allen CD, Fletcher DL, Northcutt JK, Russell SM. The relationship of broiler breast color to meat quality and shelf-life.Poultry Science 1998;77:361366.

Behmer AO, Tolosa EMC, Freitas Neto AG. Manual de Técnicas paraHistologia Normal e Patológica. 2nd ed. Barueri: Editora Manole; 2003.

Beraquet NJ. Influência de fatores ante e postmorten na qualidade da carne de aves. Revista Brasileira de CiênciaAvícola 1999;1(3):155-166.

Berri C. Variability of sensory and processing qualities of poultry meat. World's Poultry Science Journal 2000;56(3):209-224.

Campos EJ. O comportamento das aves. Revista Brasileira de Ciência Avícola 2000; 2(2):93-113.

Castro JBJ, Castillo CJC, Ortega EMM, Pedreira MS. Jejum alimentar na qualidade da carne de frangos de corte criados em sistema convencional. Ciência Rural 2008; 38(2):470-476.

Council for Agricultural Science and Technology. The well being of agricultural animals. Ames: CAST; 1997.

Duke GE, Basha M, Noll S. Optimum duration of feed and water removal prior to processing inorder to reduce the potential for fecal contamination in turkeys. Poultry Science 1997;76:516-522.

Edwards JD. The role of the veterinarian in animal welfare - a global perspective. In: Global Conference on Animal Welfare: an OIE Initiative. 2004 [cited 2005 Out 16]. Available from:<http://www.oie.int/eng/ Welfare $\% 5 F 2004 /$ home.htm>.

Maiorka A, Boleli IC, Macari M. Desenvolvimento e reparo da mucosa intestinal. In: Macari M, Furlan RL,Gonzales E. Fisiologia aviária aplicada em frangos de corte. Jaboticabal: Funep; 2002. p.113-123.
Martrenchar A, Huonnic D, CotteEB, Morisse JP. Influence of stocking density, artificial dusk and group size on the perching behavior of broilers. British Poultry Science 2000; 41:125-130.

Marx G, Leppelt J, Ellendorff EF. Vocalization in chicks (Gallus gallusdom.) during stepwise social isolation. Applied Animal Behavior Science $2001 ; 75(1): 61-74$

Mc Manus JFA, Mowry RW. Staining methods: histology and histochemical. New York: P.B. Hoeber; 1960

Mitchell MA; Carlisle AJ. The effects of chronic exposure to elevated environmental temperature on intestinal morphology and nutrient absorption in the domestic fowl (Gallus gallusdomesticus). Comparative Biochemistry and Physiology 1992;101:137-142.

Mendes AA. Jejum pré-abate em frangos de corte. Revista Brasileira de Ciência Avícola 2001;3:199-209.

Moura DJ, Nääs IA, Pereira DF, Silva RBTR, Camargo GA. Animal welfare concepts and strategy for poultry production: a review. Revista Brasileira de Ciência Avícola 2006; 8(1):137-48.

Nääs I A. Bem estar na avicultura: fatos e mitos. Revista AveWorld 2005; 10:4-8.

Northcutt JK, Burh RJ, Berrang M.E, Fletecher DL. Effects of replacement finisher feed and length of feed withdrawal on broiler carcass yield and bacteria recovery. Poultry Science 2003; 82:1820-1824.

Northcutt JK, Savage SI, Vest LR. Relationship between feed withdrawal and viscera condition of broilers. Poultry Science 1997;76:410-414.

Okamoto AS, Andreatti Filho RL, Lima ET, Noujaim CJ. Histopatologia da mucosa intestinal de pintos tratados com Lactobacillusspp. e desafiadas com Salmonellaenterica, subespécie enterica, sorotipo Enteritidis. Ciência Animal Brasileira 2009;10(2):568-573.

Qiao M, Fletcher DL, Smith DP, Northcutt JK . The effect of broiler meat color on $\mathrm{pH}$, mointure, water-holding capacity and emulsification capacity. Poultry Science 2001; 80:676-680.

SAS Institute. SAS user's guide. Cary; 2004

Shamoto K, Yamauchi K. Recovery responses of chick intestinal villus morphology to Different refeeding procedures. Poultry Science 2000;79:718-723.

Sistema para Análise Estatística e Genética. Manual de utilização do programa SAEG. Viçosa: UFV; 1998.

Smith MW, Mitchell M, Peacock MA. Effects of genetic selection on growth rate and intestinal structure in the domestic fowl (Gallus domestics). Comparative Biochemistryand Physiology 1990;97:57-63.

Thompson KL, Applegate TJ. Feed withdrawal alters small-intestinal morphology and mucus of broilers. Poultry Science 2006;85:1535 -1540 .

Van laack Rum, Liu Ch, SmithMO, Loveday HD. Characteristics of pale, soft, exudative broiler breast meat. Poultry Science 2000;79(7):1057-1061.

Yamauchi KKamisoyama HIsshiki Y. Effects of fasting and refeeding on structures of the intestinal villi and epithelial cells in White Leghorn hens. British Poultry Science 1996; 37:909-921. 